\section{O Que é a Medicina Hoje?}

\section{What is Medicine Today?}

\section{Belmiro Parada}

A produção científica, mais especificamente a participação na publicação de artigos, e incluo neste processo diversos actores, nomeadamente os autores e revisores, mas também os leitores, é muito importante na formação médica, daí ser valorizada nos diversos concursos. Aliás, temos de reconhecer que a formação técnico-científica nas "Escolas Médicas Portuguesas", desde a Faculdade até aos Internatos, é de qualidade. Contudo, esta vertente da formação é, per si, insuficiente.

Cabe-nos, enquanto actores dessa formação, transmitir conhecimento e produzir ciência, formar médicos e investigadores. Mas cabe-nos também definir que valores queremos transmitir, numa sociedade com mudanças radicais dos conceitos tradicionalmente aceites e em que se nos colocam questões que vão para além da ciência e do conhecimento, como por exemplo, a progressiva proletarização da classe, a ética na investigação, a visão economicista da saúde, a problemática do acesso aos cuidados, testamento vital, eutanásia, distanásia, entre outros.

A identidade e coerência intrínseca da medicina moderna foi descrita inicialmente em termos epistemológicos, a medicina como uma ciência natural, que só progredia através da observação sem viés no laboratório, nas salas de dissecção ou junto dos doentes, recolhendo factos e deduzindo conclusões. Esta concepção científica da medicina foi muito produtiva. Mas, o sucesso criou problemas. Com a acumulação de dados e de factos, perdeu-se a unidade e a perspectiva comum e o doente, enquanto "objecto" da medicina, não era abordado de forma adequada, uma vez que os instrumentos conceptuais eram insuficientes e demasiado simples. ${ }^{1-4}$

A necessidade de reinterpretar a medicina como ciência do "Homem" levou ao desenvolvimento do conceito de medicina antropológica, em que o pensamento e a prática médica não se restringiam aos métodos científicos. O "subjectivo" é introduzido na medicina. Como afirmou Buytendijk, "se a medicina não for objectiva, torna-se impossível mas se for apenas objectiva deixa de ser humana". Esta visão antropológica, defendida entre outros por Weizsacker, expõe a dimensão moral da medicina, numa tentativa de reconciliar a vida orgânica, o zooe, e a vida biográfica, o bios. Nesta abordagem, apesar de evolutiva, há uma tendência para o paternalismo. O doente é introduzido na "medicina" mas o seu papel é definido e está primariamente dependente da personalidade do médico. É este que usa os

Editor-chefe "seus critérios" para, a partir do conhecimento biográfico do doente, interpretar os aspectos subjectivos da doença, que muitas vezes é ocultada a quem dela padece.

Houve, assim, a necessidade de evoluir para uma abordagem ética, com participação neste processo do agente do conhecimento e agente actuante, o médico, mas também do seu "objecto de actuação", o doente. A medicina deixa de ser constituída apenas por determinantes internos, o conhecimento e as qualidades pessoais dos praticantes mas passa a incluir também, de forma ainda mais significativa, determinantes externos, as qualidades individuais dos doentes, tornando-se numa profissão única na avaliação sistemática e metódica do doente como uma pessoa irredutível. A esta luz faz pleno sentido o pensamento de Sir William Osler, o pai da Medicina Interna, ao postular que: "Antes de conhecer a doença que o homem tem, o médico deve conhecer o homem que tem a doença".

A questão, "o que é a medicina hoje?' já não consegue ser respondida pela medicina em si. Impõe-se uma nova abordagem, humanista, holística, mais voltada para o lado emocional, social e cultural, com preocupação pelos valores morais, numa inter-relação com outras ciências humanas como a Sociologia, Psicologia, Antropologia e Filosofia. Alguns conceitos dominantes, como "imortalidade" e "invulnerabilidade", assim o exigem. Implica o reconhecimento de que a medicina é ela própria parte da sociedade e da cultura. ${ }^{1-4}$

Esta abordagem humanizada pressupõe que o médico se interesse pelo paciente em aspectos não directamente afectos à doença mas englobando a dimensão pessoal, com diversas vantagens. Dá um sentido mais pleno ao seu trabalho, pressupõe uma maior satisfação de ambos, médico e doente, e proporciona uma maior eficácia da sua actuação. O importante, neste conceito, não é "o que é que sabemos?" mas, "o que queremos fazer com o nosso conhecimento?"

Esta abordagem assenta, como afirma João Lobo Antunes, "nos pilares do temperamento, do carácter, da educação, da cultura e da filosofia da profissão". Depende de "líderes" bem preparados, fortes e esclarecidos, que partilhem estes valores humanistas. ${ }^{5}$

\section{REFERÊNCIAS}

1. Ten Have H. The anthropological tradition in the philosophy of medicine. Theor Med. 1995; 16: 3-14.

2. Buytendijk FJ. De relatie arts-patient. Ned Tijdschr Geneesk. 1959; 103 : 2504-8.

3. Von Weizsacker. Der Kranke Mensch. Eine Einführung in die Medizinische Anthropologie. Stuttgart: K.F. Köhler; 1951.

4. Leone S. Humanização. In: Leone S, Privitera S., Dicionário de Bioética. Vila Nova de Gaia: Editorial Perpétuo Socorro; 2001. p.569-72.

5. Lobo Antunes J. Um Modo de Ser - Ensaios. 13ª ed. Lisboa: Gradiva; 2017. 